\title{
PENERAPAN WAKAF DI KANIGORO BLITAR (Studi Atas Pelaksanaan PP No. 28 Tahun 1977 dan UU No. 41 Tahun 2004)
}

\author{
Achmad Fatoni \\ UIN Maulana Malik Ibrahim Malang \\ Email: a_fatoni@gmail.com
}

\begin{abstract}
Abstrak
This research examines the application of waqf in Kanigoro Blitar Sub-district based on regulation 28/1977 and after the enactment of Law No. 41/2004 on the application of Endowments and inhibiting factor endowments moving objects in accordance with Law No. 41/2004 on Endowments. The study concluded that the implementation of waqf in Kanigoro before the enactment of Law no. 41 Year 2004 on endowments, namely the enactment of PP. 28 of 1977 can be applied in the field, both in terms of implementation of the procurement or obeying the rules which in this case is the rule registering legally the land. However, related to the enactment of Law No.. 41 Year 2004 regarding waqf endowments, especially on moving objects has not been effective at all.

Penelitian ini mengkaji tentang penerapan wakaf di kec. Kanigoro sesuai dengan PP 28/1977 dan sesudah berlakunya UU no 41/2004 tentang Wakaf dan faktor penghambat penerapan wakaf benda bergerak sesuai UU no 41/2004 tentang Wakaf. Penelitian menyimpulkan bahwa penerapan wakaf pada masyarakat di Kec. Kanigoro Kab. Blitar sebelum berlakunya UU No. 41 Tahun 2004 tentang wakaf, yaitu pada berlakunya PP No. 28 Tahun 1977 bisa diterapkan di lapangan, baik dalam pelaksanaan pengadaannya ataupun dari segi mentaati aturannya yang dalam hal ini adalah aturan mensertifikatkan tanahnya. Namun berkaitan dengan berlakunya UU No. 41 Tahun 2004 tentang wakaf khususnya pada wakaf benda bergerak belum efektif sama sekali
\end{abstract}

Kata Kunci: Penerapan, Wakaf

Sejak kedatangan Islam wakaf telah dilaksanakan berdasarkan paham yang dianut oleh sebagian besar masyarakat Islam Indonesia, yaitu dengan adat kebiasaan setempat, seperti halnya secara lisan yang mana hal tersebut atas dasar saling percaya kepada seseorang atau lembaga tertentu, kebiasaan memandang wakaf sebagai amal saleh yang mempunyai nilai mulia di hadirat Tuhan tanpa harus melalui prosedur administratif, dan harta wakaf dianggap milik Allah semata dan tidak akan pernah ada pihak yang berani mengganggu gugat ${ }^{1}$.

Mengingatdemikianbesarnyapahalawakaf, serta peranan obyek wakaf dalam kehidupan masyarakat Islam khususnya di Indonesia, sebagaimana telah banyak kita ketahui bahwa hampir semua obyek dari perwakafan berupa bangunan yang berfungsi sebagai sarana keagamaan, semisal sekolah, madrasah, pe-

\footnotetext{
1 Panduan Pemberdayaan Tanah Wakaf Produktif Strategis Di Indonesia, Direktorat Pemberdayaan Wakaf Direktorat Jendral Bimbingan Masyarakat Islam (Depag RI , tahun 2007), h. 61
}

santren, langgar, mushola, rumah sakit, balai pengobatan, klinik dan panti asuhan yatim². Maka sudah waktunya tanah wakaf mendapat perhatian yang khusus dalam konstelasi hukum tanah nasional

Hal ini mengingat di zaman sekarang hanya dari sebuah keihlasan dari seseorang yang menyerahkan wakaf dan orang-orang yang menerima sebagai amanat, tidak dapat dijadikan sebagai jaminan bagi kelangsungan tujuan pengelolaan harta wakaf itu sendiri, baik bagi si wakif atau mauquf alaih. Hal ini jika keduanya masih hidup biasanya mungkin tidak akan terjadi apa-apa, tapi kalau keduanya sudah meninggal dunia atau salah satu ada yang meninggal dunia maka akan menjadi lain masalahnya.

Perkembangan wakaf di Indonesia mengalami penyimpangan baik peruntukan, maupun pengurusan sehingga banyak menimbulkan sengketa antara ahli waris dari wakif dan atau ahli waris nadzir. Hal ini

2 Al- Alabi Adijani, Perwakafan Tanah Di Indonesia Dalam Teori Dan Praktek, (Raja Grafindo Persada, Jakarta, tt), h: 82 
mendorong terbentuknya Peraturan Pemerintah No. 28 Tahun 1977

Dalam praktek adanya PPNo. 28 tahun 1977 tidak dapat efektif karena di sebagian masyarakat ada yang enggan untuk mewakafkan tanahnya karena beberapa alasan. Seiring dengan adanya Peradilan Agama yang dibentuk berdasarkan Undang-Undang No. 7 Tahun 1989 tentang Peradilan Agama, dibutuhkan suatu pedoman untuk menyelesaikan sengketa tentang wakaf yang dirasa oleh hakim Pengadilan Agama masih kurang apabila hanya mendasarkan ketentuan dari PP No. 28 Tahun $1977^{3}$. Dan diberlakukanya UU No. 41 tahun 2004 pada pasal 28 tentang perwakafan benda bergerak belum bisa diterapkan. Mengingat selama ini berdasarkan PP No. 28 Tahun 1977 wakif hanya dibatasi pada orang-orang, atau badan hukum yang memiliki tanah hak milik dan obyek wakaf pun hanya dibatasi pada benda tetap yang berupa tanah hak milik saja. Untuk memberikan dorongan bagi umat Islam untuk mewujudkan pelaksanaan ibadah kepada Allah SWT melalui wakaf, kiranya tidak perlu seseorang itu menunggu mempunyai tanah hak milik. Dan cukup seseorang itu memiliki harta baik benda tetap atau benda tidak tetap, asalkan benda itu merupakan harta milik wakif secara keseluruhan dan adanya niat wakif untuk mewakafkan hartanya itu secara kekal atau terus menerus.

\section{Metode Penelitian}

Jenis penelitian ini adalah sosio-legal research atau penelitian sosio-legal. Dimana jenis penelitian ini sering kali disalahartikan sebagai penelitian hukum. Hal itu disebabkan baik pada penelitian yang bersifat sosial maupun penelitian hukum mempunyai obyek yang sama, yaitu hukum. Akan tetapi, penelitian yang bersifat sosi-legal hanya menempatkan hukum sebagai gejala sosial. Oleh karena itulah di dalam penelitian sosio-legal hukum selalu dikaitkan dengan masalah sosial. Adapun pengertian penelitian sosiolegal adalah penelitian yang menitik beratkan pelaku individu atau masyarakat dalam kaitanya dengan hukum. Berdasarkan hal tersebut, tidak dapat disangkal bahwa yang paling sering menjadi topik di dalam penelitian sosio-legal adalah masalah efektivitas aturan hukum, kepatuhan terhadap aturan hukum, peranan lembaga atau institusi hukum dalam penegakan hukum, implementasi aturan hukum, pengaruh aturan hukum terhadap masalah sosial tertentu atau sebaliknya, pengaruh masalah sosial tertentu

3 Panduan Pemberdayaan Tanah Wakaf Produktif, h. 20-34 terhadap aturan hukum. Dalam penelitian semacam itu, hukum ditempatkan sebagai variabel terikat dan faktor-faktor non hukum yang mempengaruhi hukum dipandang sebagai variabel bebas. ${ }^{4}$

Data primer, yaitu data yang secara langsung diperoleh dari masyarakat ${ }^{5}$ yang disusun dari pengumpulan data lapangan dalam pelaksanaan penelitian lapangan, yang dilakukan dengan menggunakan metode interview (tanya jawab) dengan para responden penelitian.

Tanya jawab disini akan dilakukan secara terbuka, yang dimaksudkan agar penelitian ini dapat memperoleh data yang efektif dan mendalam serta sesuai dengan kenyataan mengenai pelaksanaan maupun proses perwakafan tanah yang terjadi di lokasi penelitian. Adapun responden tersebut meliputi:beberapa orang dari pihak dari KUA Kec. Kanigoro

Data Sekunder, data yang diperoleh melalui bahan kepustakaan dikumpulkan dari berbagai tulisan, baik yang berupa laporan dari hasil penelitian sebelumnya maupun tulisan dan karya ilmiah dalam bentuk skripsi yang membahas persoalan yang sama, demikian juga pendapat para pakar mengenai hal tersebut.

\section{Pembahasan}

\section{Kondisi Keagamaan}

Jumlah penduduk di Kecamatan Kanigoro Kab. Blitar $99 \%$ beragama Islam, berdasarkan Tahun 2009 dari jadwal aktifitas rutin penduduk dalam kegiatanya yang bersifat kerohanian. Adapun Jadwal aktifitas penduduk dalam kegiatan-kegiatan yang bersifat ke$\operatorname{rohanian}^{6}$ (Tabel I).

Sedangkan terkait pada sarana tempat peribadatanya di Kec. Kanigoro berupa: 35 masjid dan 163 surau/ langgar dan juga terdapat jenis Lembaga atau Organisasi kemasyarakatan yang berupa Majlis Ta'lim/Kelompok Pengajian dan Yayasan.

Hal ini dikaji karena masalah perwakafan tanah sangat erat hubunganya dengan agama, dimana para wakif mewakafkan tanahnya karena ingin melaksanakan ajaran agama dan keinginan untuk mendapatkan pahala dalam perbuatan perwakafan tanahnya tersebut .

\footnotetext{
Peter Mahmud Marzuki, Penelitian Hukum (Jakarta: Kencana, 2007), h : 87 Rony Hanitjo Soemitro, Metodologi Penelitian Hukum (Jakarta:Ghaila Indonesia, 1983), h : 14

6 Istikharoh, wawancara (Kanigoro, 10 April 20100
} 


\section{Kondisi Ekonomi}

Berdasarkan mata pencaharianya penduduk di wilayah Kec. Kanigoro Kab. Blitar terdiri atas Pegawai Negeri, Pengusaha, Pedagang, Petani, Buruh Tani, Wiraswasta dll. Namun yang paling dominan dari sumber penghasilan utama sebagian besar penduduk adalah pertanian, dengan jumlah prosentase perkiraan 90 persen ${ }^{7}$.

Dalam bidang ekonomi di Kec. Kanigoro Kab. Blitar wakaf memegang peranan penting dalam keseimbangan kehidupan masyarakat yang vital dengan pribadi-pribadi muslim untuk memberikan sedekah apabila masyarakat membutuhkan tempat ibadah, yayasan yatim dan panti jompo dan juga bentuk dari perwakafan lainnya. ${ }^{8}$

\section{Pengertian wakaf}

Apabila ditinjau dari ketentuan syariat Islam, maka persoalan perwakafan adalah sangat sederhana, sebab hanya dilandasi pada adanya saling percaya diantara para pihak yang terlibat dalam perwakafan, tanpa proses administrasi yang baik. Sebagaimana perwakafan yang terjadi pada sebagian lokasi di Kec. Kanigoro Kab. Blitar, pada dasarnya sangat sederhana sekali, yaitu mulai dari penyerahan benda wakaf kepada pengurus, yang pelaksanaanya dengan cara tidak formal, yaitu hanya dengan sebuah pernyataan bahwa tanah tersebut telah diwakafkan kepada pihak penerima wakaf untuk dijadikan Masjid atau untuk kepentingan masyarakat setempat "Wakaf adalah

Sofyan, wawancara (Kanigoro, 9 April 20100)

8 Sahuri, wawancara (Kanigoro, 9 April 20100) pemberian sebidang tanah dari masyarakat pribadi untuk pondok atau madrasah setempat " 9

Diutarakan juga "Wakaf itu menahan harta untuk dapat dimanfaatkan untuk kepentingan umum, yang barangnya berupa tanah atau bangunan, milik pribadi dan hasilnya disalurkan untuk kepentingan umum guna mendekatkan diri kepada Allah SWT." 10 Yang diteruskan juga menurut pandangan beliau juga "Wakaf itu juga merupakan ibadah yang mengandung dua dimensi dalam hubungan manusia dengan sesama manusia juga hubungan manusia dengan Allah atau hablumminallah dan hablum minannas." ${ }^{11}$

Juga ditegaskan oleh salah satu pejabat di KUA bahwa sesuai berdasarkan UU No. 41 Tahun 2004 tentang wakaf, wakaf adalah "Wakaf itu perbuatan hukum wakif untuk menyerahkan harta benda miliknya untuk dapat dimanfaatkan dengan tidak melanggar Syariah Islam dan harus berdasar atas tujuan dari Syari'ah Islam itu sendiri"'12

\section{Dasar Hukum Wakaf}

Dalam kaitanya dengan dasar hukum wakaf, ada beberapa argumen yang dikemukakan, misalnya yang dikutip dari Hadits Rasulullah SAW yang diriwayatkan oleh Muslim dari Abi Hurairah yang terjemahannya:

\begin{tabular}{ll}
\hline 9 & Sahuri, wawancara (Kanigoro, 9 April 20100) \\
10 & Gus Taki, wawancara (Kanigoro, 9 April 20100) \\
11 & Gus Taki, wawancara (Kanigoro, 9 April 20100) \\
12 & Mahbul, wawancara (Kanigoro, 9 April 20100)
\end{tabular}

Tabel I

\begin{tabular}{|lll|}
\hline \multicolumn{1}{|c|}{ Hari } & \multicolumn{1}{c|}{ Jenis kegiatan } & \multicolumn{1}{c|}{ Tempat } \\
\hline Senin & Pengajian Rutin Ibu PKK & Kec. Kanigoro Kab. Blitar \\
& Pengajian Khataman Al Qur'an & Kec. Kanigoro Kab. Blitar \\
\hline Selasa & Pengajian Muslimat Wilayah Utara & Kec. Kanigoro Kab. Blitar \\
\hline Rabu & Pengajian Yasinan Orang Dewasa & Kec. Kanigoro Kab. Blitar \\
\hline \multirow{3}{*}{ Kamis } & Pengajian Thoriqoh Nafsha Bandhiyah & Kec. Kanigoro Kab. Blitar \\
& Pengajian Yasinan Ibu Fatayan NU & Kec. Kanigoro Kab. Blitar \\
& Pengajian Muslimat Wilayah Selatan & Kec. Kanigoro Kab. Blitar \\
\hline \multirow{3}{*}{ Jum'at } & Pengajian Rutin Pagi di Masjid & Kec. Kanigoro Kab. Blitar \\
& Pengajian Yasinan buat anak-anak & Kec. Kanigoro Kab. Blitar \\
\hline Sabtu & Pengajian Baca Dhiba' & Kec. Kanigoro Kab. Blitar \\
\hline Minggu & Pembacaan Hadhroh & Kec. Kanigoro Kab. Blitar \\
\hline Sabtu pahing & Pengajian Kuliah Subuh di Masjid & Kec. Kanigoro Kab. Blitar \\
\hline Minggu wage & Reuni Haji & Kec. Kanigoro Kab. Blitar \\
\hline
\end{tabular}




$$
\begin{aligned}
& \text { اذا مات الانسان انقطع عمله الا من ثلاث صدقة جارية أو } \\
& \text { علم ينتفع به أو ولد صالح يدعو له }
\end{aligned}
$$

"Kalau manusia mati, maka putus amalnya kecuali tiga hal yaitu sedekah jariyah, ilmu bermanfaat, dan anak yang saleh yang mendo'akannya" ${ }^{13}$

Serta pada Firman Allah QS ; Ali Imran : $92{ }^{14}$.

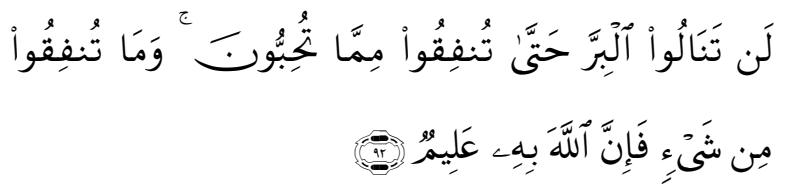

"Ibadahmu tidak sempurna, sebelum kamu memberikan sebagian harta-hartamu. Allah yang maha mengetahui "15

Diutarakankan juga "Dasar perbuatan wakaf menurut saya sesuai dengan Hadits Rasulullah :

$$
\begin{aligned}
& \text { عن عبد الله بن عمر أن عمر رضي اله عنه أنى النبي صلى } \\
& \text { الله عليه وسلم وكان قد ملك مائة سهم من خيبر فقال قد } \\
& \text { أصبت مالا لم أصب مثلّه وقد أردت أن أتقرب به إلى الله } \\
& \text { تعالى فقال حبس الأصل وسبل الثمرة }
\end{aligned}
$$

"Sahabat Umar mendapat tanah di Kota Khaibar, lalu bertanya Rasul: ya Rasul, saya mendapatkan tanah di Kota Khaibar, tanah itu sangat subur, apa yang mesti saya perbuat? Rasul menjawab : Bila kamu senang, kamu tahan tanah itu, dan kamu sedekahkan hasilnya. Kemudian Umar melakukan Shadaqah dengan tidak dijual, dihibahkan dan diwariskan. Umar berkata saya sedekahkan kepada orang-orang miskin, keluarga, tamu, budak dan yang pengurus tanah wakaf itu, asal semua ini tidak dijadikan untuk menumpuk harta ${ }^{16}$

Terkait statusnya sebagai wilayah yang mempunyai tingkat corak agama yang tinggi, mengenai landasan perwakafan, masyarakat di Kec. Kanigoro Kab. Blitar sedikit banyak mengetahui yang bisa dijadikan dasar hukum atas diberlakukanya perwakafan. Hal ini dapat kita cermati dari pemaparan di atas yang diambil mulai dari kalangan warga biasa hingga pada kalangan pejabat KUA setempat

13 Fiqih Wakaf, Direktorat Pemberdayaan Wakaf Direktorat Jendral Bimbingan Masyarakat Islam ( Depag RI, tahun 2007), h : 12.

14 Departemen agama RI, Al-Qur'an Dan Terjkemahannya (Jakarta: Proyek Pengadaan kitab Suci AL-Qur'an, 1978/1979), 91.

16 Mahbul, wawancara (Kanigoro, 9 April 20100)

\section{Syarat Rukun Wakaf}

Adapun dalam menanggapi adanya syarat rukun wakaf pada di wilayah Kec. Kanigor Kab. Blitar mengemukakan

"Menurut UU Nomor 41 Tahun 2004 unsur wakafada 6: Wakif, Nadzir; Harta benda wakaf, krar wakaf; Peruntukan harta benda wakaf dan jangka waktu wakaf. Dimana Syarat bagi berakal sehat, dewasa dan tidak berada di bawah pengampuan. Pada Benda yang diwakafkan berlaku syarat: Harus mempunyai nilai baik pada benda tetap atau benda bergerak dan tujuan harus sesuai dengan Syari'at Islam." ${ }^{\prime 7}$

Selanjutnya disambung oleh Bapak Mahbul "Peruntukan wakaf mesti berupa: Sarana ibadah, kegiatan pendidikan dan kesehatan, atau buat kemaslahatan fakir miskin, kemaslahatan masyarakat dengan tidak menyeleweng dengan syari'ah agama dan peraturan perundang-undangan". ${ }^{18}$

Berikutnya menurutnya "lafadh ikrar berarti ucapan yang tertulis atau isyarat dari wakif untuk tujuan wakaf sesuai yang diinginkan wakif"19

Dalam menanggapi masalah syarat rukun wakaf di atas dapat dipahami bahwa dalam penjabaranya mereka hanya menggunakan dasar UU No, 41 Tahun 2004 tentang wakaf, yang mana persyaratan disini memiliki 6 unsur, yaitu sesuai dengan pasal 6 yang berbunyi "Wakaf dilaksanakan dengan memenuhi unsur wakaf sebagai berikut: a) Wakif; b) Nazhir; c) Harta Benda Wakaf; d) Ikrar Wakaf; e) Peruntukan harta, f) Jangka waktu wakaf".

Sedangkan pada wakaf berdasarkan pada Fiqh dan PP No. 1977 pasal 1 syarat rukun wakaf meliputi 4 unsur, yaitu : (1) Wakif, (2) Mauquf, (3) Mauquf 'alaih, (4) Ikrar wakaf.

\section{Tujuan Wakaf}

Adapun mengenai tujuan dilaksanakanya perwakafan pada masyarakat di Kec. Kanigoro Kab. Blitar mengutarakan beberapa pointnya, yaitu:

"Aku berwakaf untuk kesejahteraan warga dan kemaslahatan umat"20, "Sewaktu saya ngaji dulu

17 Lis, wawancara (Kanigoro, 10 April 2010)

18 Mahbul, wawancara (Kanigoro, 10 April 2010)

19 Mahbul, wawancara (Kanigoro, 10 April 2010)

20 Sahuri, wawancara (Kanigoro, 10 April 2010) 
wakaf itu untuk mendapatkan pahala yang akan terus mengalir seperti Hadits dari Rasulullah"21, Memperoleh keridhoan Allah ${ }^{22}$. Ada beberapa tujuan perwakafan yang dapat kita maknai dari pemaparan ini, yaitu: (a) Untuk kesejahteraan , seperti (tempat) mendirikan masjid, sekolah, rumah sakit, (b) Untuk mendapatkan pahala yang terus meneurs, meskipun keberadaan wakif sudah meninggal dunia, (c) Tujuan wakaf adalah untuk mendapatkan keridhaan Allah, dalam rangka beribadah kepada-Nya. seperti sama halnya dengan zakat, wakaf merupakan ibadah amaliah berbentuk shadaqah jariyah yakni shadaqah yang terus mengalir pahalanya untuk orang yang menyedekahkan selama barang atau benda yang disedekahkan masih ada dan dimanfaatkan. Sebagaimana hadits Rasulullah saw. yang berbunyi:

$$
\begin{aligned}
& \text { اذا مات ابن آدم انقطع عمله الا من ثلاث صدقة جارية او } \\
& \text { علم ينتفع به او ولا صالح يدعوله } \\
& \text { قرو اه مسلم }
\end{aligned}
$$

(HR. Muslim).

\section{Tata Cara Perwakafan}

Pada masyarakat di Kec. Kanigoro Kab. Blitar ada beberapa bentuk tata cara perwakafan yang mereka kemukakan, yaitu:

"Bagi orang yang berwakaf harus orang baik dan dilakukannya dengan sukarela"

"Penerima wakaf harus jelas status
keberadaanya"23

Dari pemaparan di atas dapat di jabarkan bahwa tata cara perwakafan yaitu harus melalui tahapan, yaitu

Bagi orang yang berwakaf (wakif), disyaratkan bahwa ia adalah orang yang ahli berbuat baik dan perbuatan mewakafkan yang dilakukannya itu adalah secara suka rela dan bukan karena ia dipaksa, seperti juga dengan disyaratkan bagi si penjual dan pembeli, maka yang dimaksudkan dengan "ahli berbuat baik" di sini adalah orang yang mempunyai akal (yaitu tidak gila atau tidak bodoh) tidak mubadzir (karena harta orang mubazir berada di bawah penguasaan walinya), dan baligh.

21 Agus, wawancara (Kanigoro, 10 April 2010)

22 Agus, wawancara (Kanigoro, 10 April 2010)

23 Dikutip dari hasil wawancara dengan Bp. Sahuri selaku wakif pada tanggal 10 April 2010
Untuk mewakafkan harta benda wakaf, maka diperlukan penjelasan atau keterangan tentang siapa yang diwakafkan benda wakaf tersebut, karena orang yang akan menerima benda wakaf yang diwakafkan oleh si wakif telah berada di tempat terjadinya perwakafan. Oleh karena itu, tidaklah sah wakaf suatu benda untuk seorang anak yang belum lahir, dan tidaklah dianggap sah wakaf kalau seseorang misalnya hanya dengan berkata: "Saya wakafkan rumah ini" karena ucapan ini tidak terang atau pun jelas pada siapa benda akan diwakafkan serta apa manfaatnya mewakafkan harta benda tersebut, maka kalau si penerima harta wakaf itu adalah pihak-pihak tertentu.

\section{Penerapan Wakaf di Kec. Kanigoro kab. Blitar Se- belum Berlakunya UU No. 41 Tahun 2004 tentang Wakaf}

Sebelum berlakunya UU No. 41 Tahun 2004 tentang wakaf, lahirlah peraturan lainya yang juga mengatur keberadaan wakaf tersebut yaitu diantaranya diberlakunya PP No. 28 Tahun 1977, dimana dalam dalam Peraturan Pemerintah ini memberikan pengertiannya mengenai wakaf yang disebutkan dalam pasal 1 ayat (1) yang berbunyi "Wakaf adalah perbuatan hukum seseorang atau badan hukum yang memisahkan sebagian dari harta kekayaannya yang berupa tanah milik dan melembagakannya untuk selama-lamanya untuk kepentingan peribadatan atau keperluan umum lainya sesuai dengan ajaran agama Islam.

Harta wakaf pada prinsipnya adalah milik umat, dengan demikian manfaatnya juga harus dirasakan oleh umat dan oleh karena itu pada tataran idealnya maka harta wakaf adalah tanggung jawab kolektif guna menjaga keeksisannya. Wakaf merupakan salah satu lembaga hukum Islam. Hukum Islam adalah suatu sistem hukum yang mendasarkan pada ajaran agama Islam. Agama Islam merupakan ajaran agama yang sempurna. Mengatur seluruh kehidupan alam seisinya, termasuk mengatur kehidupan manusia. Dalam menjalani kehidupannya manusia dapat memiliki harta, tetapi kepemilikan harta itu tidak mutlak. Harta adalah milik Allah SWT dan dititipkan kepada manusia yang dikehendaki-NYA. Harta yang dimiliki oleh umat Islam sebagian adalah hak dari manusia yang lemah. Oleh karena itu Islam mengajarkan memberikan sedekah, zakat dan wakaf terhadap harta yang dimiliki untuk kepentingan agama.

Perkembangan wakaf di Kec. Kanigoro Kab. Blitar dimulai dari adanya wakaf yang telah ada pada masyarakat hukum adat, dimana hal ini dapat diartikan juga sebagai suatu perbuatan hukum dengan mana 
perbuatan suatu barang/ barang keadaan telah telah dikeluarkan/ diambil kegunaannya dalam lalu lintas masyarakat semula, guna kepentingan seseorang/ orang tertentu atau guna seseorang maksudnya/ tujuan/ barang tersebut sudah berada dalam tangan yang mati

Sedangkan menurut Ter Haar, wakaf merupakan suatu perbuatan hukum yang rangkap maksudnya adalah perbuatan itu disatu pihak adalah perbuatan mengenai tanah atau benda yang menyebabkan obyek itu mendapat kedudukan hukum yang khusus tetapi di lain pihak seraya perbuatan itu menimbulkan suatu badan dalam hukum adat ialah suatu badan hukum yang sanggup ikut serta dalam kehidupan hukum sebagai subyek hukum.

Sesudah zaman kemerdekaan, selain untuk tempat ibadah perwakafan di Kec. Kanigoro Kab. Blitar juga difungsikan untuk tempat pendidikan, untuk fakir miskin, perkuburan, lembung desa, jalan umum, tugu pahlawan dan panti asuhan. Dari sini nampak bermacam-macam tujuan suatu perwakafan, yang pada hakekatnya untuk kesejahteraan masyarakat, dimana hal ini dapat diartikan dengan beberapa makna yaitu untuk perjuangan kemerdekaan yang berupa untuk makam pahlawan, untuk kesejahteraan masyarakat di bidang sosial ekonomi yang berupa untuk lembung desa, dan untuk menyemarakkan semangat patriotisme dalam melawan penjajah yaitu dengan membangun tugu pahlawan dan makam pahlawan.

Dari sini nampak peranan wakaf amatlah besar bagi kehidupan masyarakat di Kec. Kanigoro Kab. Blitar lebih-lebih bagi perkembangan serta kemajuan di wilayah ini, di mana bisa diartikan kalau ada warga yang beragama Islam bersedia dengan hati ikhlas untuk mewakafkan harta bendanya menurut kemampuan mereka atau kesanggupan yang mereka miliki, maka keadaan masyarakat, penduduk dan umat Islam secara khusus akan bertambah maju dan berkembang dengan kehidupan secara aman, damai serta rukun dan sejahtera.
Tampaknya kesemua ini tidak terlepas dari ketentuan ajaran agama yang memang di sini dirasa sangat kental, dimana ketentuan ajaran itu tujuannya adalah taqarrub atau mendekatkan diri kepada Allah SWT. yaitu untuk mendapatkan kebaikan dan mengharapkan ridha-Nya, di mana perbuatan mewakafkan harta ini adalah lebih utama dan jauh lebih besar pahalanya daripada bersedekah biasanya, karena sifat perbuatan mewakafkan benda adalah bersifat kekal dan pahalanya pun adalah lebih besar. Bisa dikatakan pahala bagi orang yang mewakafkan harta bendanya akan mengalir terus kepada siapa yang mewakafkan tersebut. Walaupun yang mewakafkan hata benda itu telah meninggal dunia, sesuai dengan QS

$$
\text { علم ينتفع باه أو ولد صالح يدعان انقع عمله الا من ثلاث صدقة جارية أو }
$$

"Apabila mati anak adam maka terputuslah dari padanya semua amalnya kecuali tiga hal yaitu sedekah jariah, ilmu bermanfaat, dan anak yang saleh yang mendo'akannya" 24

Berikut terkait dengan kondisi penerapan wakafnya di Kec. Kanigoro Kab. Blitar bisa dibilang sudah efektif, dimana hal ini juga dibuktikan dengan tabel keberadaaan wakaf yang terjadi pada Kab. Blitar (Tabel II).

Berdasarkan tabel di bawah dapat diketahui data tanah wakaf tahun $2001 \mathrm{~s} / \mathrm{d}$ tanggal 31 Desember 2007 terdapat 904 bidang tanah wakaf dengan luas tanah 466.831,63 m2. Dari jumlah itu terdapat 136 bidang tanah wakaf yang baru berdasarkan akta ikrar wakaf (seluas 36.268,36 m2) serta 32 bidang tanah wakaf yang belum diproses BPH (seluas 180,750 m2). Dari jumlah itu dapat diketahui bahwa terdapat 736 bidang tanah wakaf dengan luas $430.382,52 \mathrm{~m} 2$ yang sudah mempunyai sertifikat wakaf . Apabila dinya-

24 Fiqih Wakaf, Op. Cit., 12.

Tabel II

\begin{tabular}{|c|c|c|c|c|c|c|c|c|c|c|}
\hline \multirow{2}{*}{ No } & \multirow{2}{*}{$\begin{array}{c}\text { Kabupaten } \\
\text { / Kota }\end{array}$} & \multicolumn{2}{|c|}{$\begin{array}{c}\text { JML. TANAH } \\
\text { WAKAF }\end{array}$} & \multicolumn{2}{|c|}{$\begin{array}{c}\text { BARU BER } \\
\text { AIW / APAIW }\end{array}$} & \multicolumn{2}{|c|}{ PROSES BPN } & \multicolumn{2}{|c|}{$\begin{array}{c}\text { BELUM } \\
\text { DIPROSES }\end{array}$} & \multirow{2}{*}{ KET. } \\
\hline & & BID. & $\begin{array}{l}\text { LUAS } \\
\left(\mathrm{M}^{2}\right)\end{array}$ & BID. & LUAS $\left(\mathrm{M}^{2}\right)$ & BID. & LUAS & BIDANG & $\begin{array}{l}\text { LUAS } \\
\left(\mathrm{M}^{2}\right)\end{array}$ & \\
\hline \multirow[t]{2}{*}{1} & 2 & 3 & 4 & 5 & 6 & 7 & 8 & 9 & 10 & 11 \\
\hline & BLITAR & 904 & $466.831,63$ & 136 & $36.268,36$ & - & - & 32 & 180.750 & \\
\hline
\end{tabular}

Data Tanah Wakaf Tahun 2001 s/d 31 Desember 2007 di Kab. Blitar 
takan dalam presentase terdapat $18,58 \%$ yang masih belum mempunyai sertifikat wakaf. Sedangkan tanah wakaf yang sudah bersertifikat di wilayah Kab. Blitar sebesar 82,42 \%. Jumlah itu menunjukkan bahwa masyarakat Kab. Blitar telah mematuhi ketentuan PP No. 28 Tahun 1977 dalam hal melakukan perwakafan tanah miliknya. ${ }^{25}$

Adapun menurut data yang diambil dari tabel tata cara wakaf di KUA Kec. Kanigoro Kab. Blitar pada masa sebelum berlakunya UU No. 41 Tahun 2004 tentang wakaf, ada dua masa perwakafan yang sudah efektif dilakukan yaitu masa sebelum berlakunya PP No. 28 Tahun 1977 dan masa sesudah berlakunya PP No. 28 Tahun 1977 "Dalam melaksanakan wakaf masyarakat di Kec. Kanigoro Kab. Blitar memakai tahapan prosedur wakaf yang setelah berlakunya PP No. 28 Tahun 1977 seperti pada tabel diatas, jadi mereka sudah tidak memakai prosedur yang lama"

Dari paparan diatas dapat dikaji bahwa penerapan wakaf sebelum diundangkanya UU No. 41 tahun 2004 tentang wakaf pada wilayah masyarakat Kec. Kanigoro Kab. Blitar terdapat dua prosedur tahapan pelaksanaan, yaitu tata cara penerapan wakaf sebelum dan sesudah berlakunya PP No. 28 Tahun 1977.

Adapun Pelaksanaan Perwakafan pada masa sebelum adanya PP No. 28 Tahun 1977 di Masyarakat Kec. Kanigoro Kab. Blitar mempunyai prosedur tahapan sebagai berikut:26 (a) Sebuah keluarga sedang bermusyawarah untuk berwakaf tanah milik, (b) Kepala (selaku wakif), saksi dan nadzir pergi ke Kantor KUA menghadap Kepala KUA selaku pejabat pembuat akta ikrar wakaf(PPAIW), (c) PPAIW memeriksa persyaratan wakaf dan selanjutnya mengesahkan nadzir, (d) Wakif mengucapkan ikrar wakaf dihadapan saksi-saksi dan PPAIW. Untuk selajutnya PPAIW membuat akta ikrar wakaf (AIW) dan salinanya, (e) Wakif nadzir, dan nadzir pulang dengan membawa salinan AIW (W.2A), (f) PPAW atas nama nadzir menuju ke Kantor Pertanahan Kabupaten/ Kodya dengan membawa berkas permohonan pendaftar tanah wakaf dengan pengantar formulir W-7, (g) Kantor Pertanahan memproses sertifikat tanah wakaf, (h) Kepala Kantor Pertanahan menyerahkan sertifikat tanah wakaf kepada nadzir, dan selanjutnya ditujukan kepada PPAW untuk dicatat pada daftar akta ikrar wakaf formulir W.4.

Sedangkan pelaksanaan perwakafan pada masa sesudah berlakunya PP No. 28 Tahun 1977 di Masya-

\footnotetext{
25 http://suhrawardilubis.multiply.com

26 Di peroleh dari data tabel di Kantor KUA Kec. Kanigoro Kab. Blitar yang Diterbitkan oleh Separtemen Agam RI
}

rakat Kec. Kanigoro Kab. Blitar mempunyai prosedur tahapan sebagai berikut: ${ }^{27}$ (1) Nadzir atau turunan nadzir, wakif atau turunan nadzir, masyarakat atau Kepala Desa pegi kekantor KUA menghadap PPAIW melaporkan tanah wakaf yang diketahuinya menggunakan formulir W.D, (2) PPAIW meneliti kebenaran tanah tersebut, dapat diyakini sebagai tanah wkaf atau bukan dan selanjutnya mengesahkan nadzir, (3) PPAIW membuat APAW (W-3) dan salinanya (W.3A), (4) Para pelapor atau nadzir dengan adanya membawa salinan APAIW (W.3A), (5) PPAW, atas nama nadzir menuju kantor pertanahan Kabupaten/ Kodya, dengan membawa permohonan pendaftaran tanah wakaf, dengan pengantar formulir W-7, (6) Kantor pertanahan memproses sertifikat tanah wakaf, (7) Kepala Kantor Pertanahan menyerahkan sertifikat tanah wakaf kepada nadzir dan selanjutnya dilanjutkan ditunjukkan kepada PPAW, untk dicatat pada akta pengganti akta ikrar wakaf formulir W.4A.

\section{Penerapan Wakaf di Kec. Kanigoro Kab. Blitar Sesudah Berlakunya UU No. 41 Tahun 2004 tentang Wakaf}

Dalam perjalanannya adanya ketentuan PP No. 28 Tahun 1977 ternyata dirasa masih kurang, lebihlebih setelah melihat kebutuhan masyarakat para calon wakif yang hendak melakukan wakaf dalam jumlah nominal yang terbatas, mengingat PP No. 28 Tahun 1977 ini hanya membatasi obyek wakaf hanya pada tanah hak milik saja yang tidak mencakup harta lainnya yang dimiliki oleh wakif.

Perjuangan untuk membuat payung hukum kegiatan wakaf dalam bentuk Undang-undang terus digalakkan oleh berbagai kalangan. Akhirnya, pihak Pemerintah Indonesia mengeluarkan UndangUndang (UU) Nomor 41 Tahun 2004 tentang Wakaf dan Peraturan Pemerintah (PP) Nomor 42 Tahun 2006 tentang pelaksanaan Undang-undang Nomor 41 Tahun 2004. Peraturan perundang-undang tersebut antara lain mengatur bentuk benda wakaf, yaitu benda tetap, dan benda tidak tetap dan uang. Hal ini dapat dilihat dalam ketentuan yang terdapat dalam Pasal $28 \mathrm{~s} / \mathrm{d}$ 31 UU No 41 Tahun 2004 dan Pasal 22 s/d 27 PP No 42 Tahun 2006. Dari keberadaan wakaf dengan jenis ini dapat teridentifikasi ada beberapa manfaat yang bisa dirasakan, diantaranya yaitu: ${ }^{28}$ (1) Wakaf uang jumlahnya bisa bervariasi sehingga seseorang

\footnotetext{
27 Di peroleh dari data tabel di Kantor KUA Kec. Kanigoro Kab. Blitar yang Diterbitkan oleh Separtemen Agam RI

28 http://meetabied wordpress.com/2009/10/30/tinjauan-tentang-perwakafandi-Indonesia
} 
yang memiliki dana terbatas sudah bisa mulai memberikan dana wakafnya tanpa harus menunggu menjadi tuan tanah terlebih dahulu,(2) Melalui wakaf tunai, aset wakaf yang berupa tanah-tanah kosong dapat dimanfaatkan untuk pembangunan gedung atau diolah lahan pertanian,(3) Dana wakaf tunai juga bisa membantu sebagai lembaga pendidikan Islam yang cash flownya terkadang kembang kempis dan menggaji civitas akademika ala kadarnya, (4) Pada gilirannya Insya Allah umat Islam dapat lebih mandiri dalam mengembangkan dunia pendidikan tanpa harus selalu tergantung pada anggaran pendidikan Negara yang terbatas, (5)Siapapun Bisa. Kini, orang yang ingin wakaf tidak harus menunggu menjadi kaya. Minimal Rp. 1.000.000 (satu juta rupiah), anda sudah bisa menjadi wakif (orang yang berwakaf), dan mendapat Sertifikat Wakaf Uang, (6) Jaringan Luas, kapan pun dan di manapun anda bisa setor wakaf uang. Mudah bukan? Sebab, BWI telah bekerjasama dengan Lembaga Keuangan Syariah untuk memudahkan penyetoran, (7) Uang Tak Berkurang. Dana yang diwakafkan, sepeser pun, tidak akan berkurang jumlahnya. Justru sebaliknya, dana itu akan berkembang melalui investasi yang dijamin aman, dengan pengelolaan secara amanah, bertanggung jawab, professional, dan transparan,(8) Manfaat berlipat, hasil investasi dana itu akan bermanfaat untuk peningkatan prasarana ibadah dan sosial, serta kesejahteraan masyarakat (social benefit),(9) Investasi Akhirat, manfaat yang berlipat itu menjadi pahala wakif yang terus mengalir, meski sudah meninggal, sebagai bekal di akhirat.

Wakaf uang hukumnya adalah dibolehkan, dengan cara menjadikan uang sebagai modal usaha dan keuntungannya disalurkan pada penerima wakaf, hal ini didasari dengan adanya beberapa landasan dalam fiqh, yaitu diantaranya ${ }^{29}$

Firman Allah QS Al Imran : 92

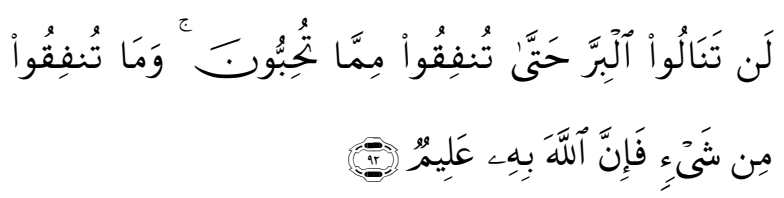

"Kamu sekali-kali tidak sampai kepada kebajikan (yang sempurna), sebelum kamu menafkahkan sebahagian harta yang kamu cintai. dan apa saja yang kamu nafkahkan Maka Sesungguhnya Allah mengetahuinya".

Firman Allah QS Al Baqarah: 261

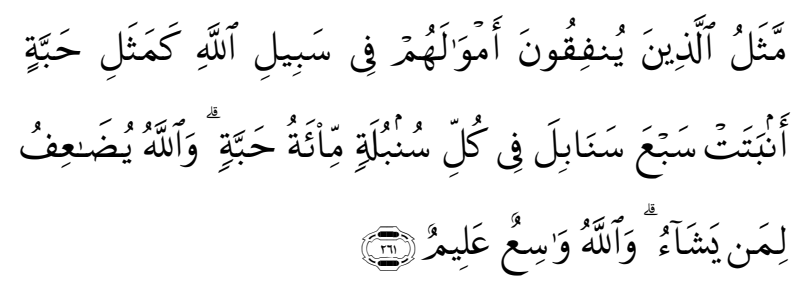

"Perumpamaan (nafkah yang dikeluarkan oleh) orang-orang yang menafkahkan hartanya di jalan Allah (166) adalah serupa dengan sebutir benih yang menumbuhkan tujuh bulir, pada tiap-tiap bulir seratus biji. Allah melipat gandakan (ganjaran) bagi siapa yang dia kehendaki. dan Allah Maha luas (karuniaNya) lagi Maha Mengetahui".

Wakaf uang mampu membuka peluang yang unik untuk menciptakan investasi guna memberikan pelayanan keagamaan, layanan pendidikan, dan layanan sosial. Tabungan orang-orang kaya dapat

29 Direktorat Pemberdayaan Wakaf Direktorat Jenderal Bimbingan Masyarakat Islam, Pedoman Pengelolaan Wakaf Tunai, (Jakarta: 2007), 16

Tabel III

Tabel Potensi Wakaf Uang di Indonesia

\begin{tabular}{|ccccc|}
\hline $\begin{array}{c}\text { Tingkat Penghasilan } \\
\text { / bulan }\end{array}$ & Jumlah Muslim & $\begin{array}{c}\text { Tarif Wakaf/ } \\
\text { bulan }\end{array}$ & $\begin{array}{c}\text { Potensi Wakaf } \\
\text { Tunai / bulan }\end{array}$ & $\begin{array}{c}\text { Potensi Wakaf } \\
\text { Tunai / tahun }\end{array}$ \\
\hline Rp 500.000 & 4 juta & Rp 5000,- & Rp 20 Milyar & Rp 240 Milyar \\
\hline Rp 1 juta -Rp 2 juta & 3 juta & Rp 10.000 & Rp 30 Milyar & Rp 360 Milyar \\
\hline Rp 2 juta - Rp 5 juta & 2 juta & Rp 50.000 & Rp 100 Milyar & Rp 1,2 Triliun \\
\hline Rp 5 juta- Rp 10 juta & 1 juta & Rp 100.000 & Rp 100 Milyar & Rp 1,2 Triliun \\
\hline & & Total & & Rp 3 Triliun \\
\hline
\end{tabular}


dimanfaatkan dengan menukarkannya dengan CashWaqf Certificate. Hasil pengembangan wakaf yang diperoleh dari sertifikat tersebut dapat dimanfaatkan untuk tujuan-tujuan yang bermacam-macam seperti tujuan-tujuan wakaf itu sendiri. Kegunaan lain dari Cash-Waqf Certificate adalah bahwa dia dapat mengubah kebiasaan lama di mana kesempatan wakaf seolah-olah hanya untuk orang-orang kaya saja. ${ }^{30}$

Dalam hal ini Mustafa Edwin Nasution pernah melakukan asumsi bahwa jumlah penduduk Muslim kelas menengah di Indonesia sebanyak 10 juta jiwa dengan rata-rata penghasilan perbulan antara $\mathrm{Rp}$ 500.000,00 (lima ratus ribu rupiah) - $\mathrm{Rp} 10.000 .000,00$ (sepuluh juta rupiah) maka dapat dibuat perhitungan sebagai berikut (Tabel III) ${ }^{31}$.

Pertama apabila umat Islam yang berpenghasilan Rp500.000,00 sejumlah 4 juta orang dan setiap tahun masing-masing berwakafsebanyak Rp60.000,00 maka setiap tahun terkumpul Rp240.000.000.000,00, kedua apabila umat yang berpenghasilan antara Rp1.000.000,00 - Rp2.000.000,00 sejumlah 3 juta orang dan setiap tahun masing-masing berwakaf Rp120.000,00 maka setiap tahun terkumpul dana sebanyak Rp360.000.000.000,00.

Ketiga apabila umat yang berpenghasilan Rp2.000.000,00 - Rp5.000.000,00 sejumlah 2 juta orang dan setiap tahun masing-masing berwakaf Rp600.000,00 maka setiap tahun terkumpul dana sebanyak Rp1.200.000.000.000,00, dan keempat apabila umat yang berpenghasilan Rp5.000.000,00 - Rp10.000.000,00 sejumlah 1 juta orang dan setiap tahun masing-masing berwakaf Rp1.200.000,00 maka setiap tahun terkumpul dana sebanyak Rp1,200.000.000.000,00.

Dengan demikian wakaf yang terkumpul selama satu tahun sejumlah Rp3.000.000.000.000,00. Berdasarkan contoh perhitungan di atas maka terlihat bahwa keberhasilan lembaga untuk memobilisasi dana wakaf akan sangat menentukan manfaat keberadaan lembaga wakaf. Yang menjadi masalah, uang tersebut tidak dapat langsung diberikan kepada mauquf 'alaih, tetapinazhir harus mengelola dan mengembangkannya terlebih dahulu. Yang harus disampaikan kepada mauquf 'alaih adalah hasil investasi dana Rp.3 triliun tersebut, sedangkan uang wakafnya sendiri tidak boleh berkurang sedikit pun. ${ }^{32}$

Wakaf uang bisa diberikan oleh siapa saja tanpa

\footnotetext{
30 http://abdullah-ubaid.glogspot.com/2008/04/membangkitkan-perwakafandi-Indonesia

31 Ibid

32 http://abdullah-ubaid.glogspot.com/2008/04/membangkitkan-perwakafandi-Indonesia
}

harus menunggu kaya. Wakaf uang akan tetap dan dikelola secara transparan dan aman.

Indonesia memiliki peran besar dalam mengembangkan wakaf uang. Sudan dan Bangladesh sudah memiliki bank khusus wakaf.

Wakaf uang diharapkan dapat menjadi sarana bagi rekonstruksi sosial dan pembangunan, di mana mayoritas penduduk dapat ikut berpartisipasi. Untuk mewujudkan partisipasi tersebut, maka berbagai upaya pengenalan tentang arti penting wakaf uang sebagai sarana mentransfer tabungan si kaya kepada para usahawan (entrepreneurs) dan anggota masyarakat dalam mendanai berbagai kegiatan di negara-negara Islam perlu dilakukan secara intensif. ${ }^{33}$

Namun kiranya semua pemaparan diatas belum bisa diberlakukan di Kec. Kanigoro Kab. Blitar, dimana hal ini terbukti dengan tidak adanya satu perwakafan pun pendataan di KUA setempat yang mencatat adanya wakaf jenis tersebut, yang didasari dengan berlakunya UU No. 41 Tahun 2004 tentang wakaf. Dari sini peneliti berpendapat bahwa efektifitas wakaf di Kec Kanigoro Kab. Blitar setelah berlakunya UU No. 41 Tahun 2004 tentang wakaf benda bergerak belum bisa di terapkan.

\section{Kesimpulan}

Penerapan wakaf pada masyarakat di Kec. Kanigoro Kab. Blitar sebelum berlakunya UU No. 41 Tahun 2004 tentang wakaf, yaitu pada berlakunya PP No. 28 Tahun 1977 bisa diterapkan di lapangan, baik dalam pelaksanaan pengadaannya ataupun dari segi mentaati aturannya yang dalam hal ini adalah aturan mensertifikatkan tanahnya, di mana hal ini bisa diketahui dari keberadaan tabel wakaf yang ditunjukkan terhitung dari Tahun 2001 s/d Tanggal 31 Desember Tahun 2007, yang terdapat 904 bidang tanah wakaf dengan luas 466.831,63 $\mathrm{m} 2$, dan dari sini terdapat 736 bidang tanah wakaf dengan luas 430.382,52 $\mathrm{m} 2$ yang sudah bersertifikat, dari keadaan ini bisa dartikan juga bahwa Pada wilayah Kec. Kanigoro Kab. Blitar terhitung dari Tahun $2001 \mathrm{~s} / \mathrm{d} 31$ Desenber 2007 terdapat $82,42 \%$ telah mematuhi keberadaan PP No. 28 Tahun 1977. Namun berkaitan dengan berlakunya UU No. 41 Tahun 2004 tentang wakaf khususnya pada wakaf benda bergerak pada wilayah Kec. Kanigoro Kab. Blitar ini bisa dibilang belum efektif sama sekali, dimana hal ini juga ditunjukkan dengan belum adanya catatan sama sekali dalam KUA wilayah Kec. Kanigoro Kab. Blitar tentang perwakafan tersebut, juga

33 http://abdullah-ubaid.glogspot 
tercermin dari argumen-argumen penduduknya yang masih bersifat asing atau kurang dikenal di kalangan mereka tentang perwakafan tersebut.

\section{Saran}

Yang harus dimengerti oleh Pemerintah bahwa dengan pengaruh yang dialami oleh perkembangan dan pembentukan hukum di negara Indonesia maka perlu untuk menyusun kekuatan tata aturan atau perundang-undangan hukum yang wajib dipedomani, selain itu pula haruslah dapat mengimbangi adanya etika hukum yang berlaku yaitu baik dan buruknya, adil atau tidaknya, cocok atau tidaknya dan segala bentuk pengembangan kebutuhan masyarakat, oleh karena itu maka ada hubungannya dengan ditaati atau tidaknya hukum itu dalam suatu kondisi masyarakat.

Jadi ketaatan pada hukum yang berlaku, erat kaitannya dengan kesadaran hukum, karena tanpa kesadaran hukum sukar diharapkan orang akan taat akan hukum tetapi semakin tinggi tingkat kesadaran hukum seseorang semakin tinggi pula ketaatannya

\section{Daftar Pustaka}

Al- Alabi Adijani. 2005. Perwakafan Tanah Di Indonesia Dalam Teori Dan Praktek. Jakarta: Raja Grafindo Persada.

Data tabel di Kantor KUA Kec. Kanigoro Kab. Blitar yang Diterbitkan oleh Separtemen Agam RI.

Departemen agama RI (1978-1979) Al-Qur'an Dan Terjkemahannya, Jakarta: Proyek Pengadaan kitab Suci AL-Qur'an.

Direktorat Pemberdayaan Wakaf Direktorat Jendral Bimbingan Masyarakat Islam Depag RI. 2007. Panduan Pemberdayaan Tanah Wakaf Produktif Strategis Di Indonesia, Jakarta.

Direktorat Pemberdayaan Wakaf Direktorat Jendral Bimbingan Masyarakat Islam Depag RI (2007) pada hukum. Sebaliknya kesadaran hukum yang rendah akan mengakibatkan kurangnya kepatuhan atau ketaatan terhadap hukum.

Dalam kenyataannya kesadaran hukum akan terbina dengan baik apabila hukum yang diciptakan tersebut sesuai dengan perasaan dan keyakinan religius, yang mayoritas beragama Islam, maka setiap norma hukum yang diciptakan harus diusahakan tidaklah bertentangan dengan adanya keyakinan masyarakat terhadap ajaran agama yang dianutnya dan adapun peraturan hukum yang bertentangan dengan keyakinan mereka maka kesadaran hukum pasti tidak dapat berjalan lancar.

Oleh karena itu, dalam pembinaan hukum nasional tidak dapat dihindari bahwa materi hukum Islam harus pula diperhatikan demi ketertiban di dalam kehidupan masyarakat pada umumnya. Menyia-nyiakan keyakinan dan kesadaran hukum maka masyarakat akan dapat menimbulkan keresahan yang akan berpengaruh terhadap stabilitas masyarakat tersebut.

\section{Fiqih Wakaf.}

Peter Mahmud Marzuki. 2007. Penelitian Hukum. Jakarta: Kencana.

Rony Hanitjo Soemitro. 1983. Metodologi Penelitian Hukum, Jakarta:Ghaila Indonesia.

http://meetabiedwordpress.com/2009/10/30/tinjauantentang-perwakafan-di ndonesia Direktorat Pemberdayaan Wakaf Direktorat Jenderal Bimbingan Masyarakat Islam, Pedoman Pengelolaan Wakaf Tunai, (Jakarta: 2007 http://abdullah-ubaid.glogspot.com/2008/04/ membangkitkan perwakafan diindonesia http : //id. Wikipedia.org/wiki/Kanigoro,_Blitar 